\section{The Institute of Museum and Library}

Services has awarded more than $\$ 10$ million to institutions of higher education, museums, and related organizations across the country for exemplary leadership in library and information science. Among the award recipients are San Jose State University; College of Micronesia, Kolonia, Phonpei, in the Federated State of Micronesia; Southeastern Library Network (SOLINET); Louisiana State University; University of Minnesota; University of Missouri; Kent State University; University of the Virgin Islands; University of Wisconsin, Milwaukee; University of California, Berkeley; Regents of the University of California; University of Illinois at Urbana-Champaign; Eastern Iowa Community College District; University of Kentucky; Johns Hopkins University; Wayne State University; Gustavus Adolphus College; University of South Carolina, Spartanburg; University of Texas, Austin; Washington State Library; University of Denver; University of Miami; University of Georgia; Illinois State Library; Amistad Research Center; University of Missouri, Columbia; Syracuse University; University of North Carolina, Chapel Hill; University of Virginia Health Sciences Library; California Digital Library; Huntington Library and Art Gallery; Triton College; Kansas State Historical Society; and Carnegie Mellon University. For cletails about the award projects, see http://wwo.imls.gov.

\section{Heritage College received a $\$ \mathbf{2 0 0 , 0 0 0}$}

grant from the William H. Gates Foundation to automate the library. The grant includes Heritage College's share of the cost of the Online Private Academic Library Link (OPALL) Consortium's Endeavor Voyager system, plus computer hardware, infrastructure, training costs, and a 40-week paid internship for a new MLS graduate or graduate student to assist with end user training. OPALL is a consortium of independent college libraries in Oregon and Washington.

Ed. note: Send your news to: Grants \& Acquisitions, C\&RL News, 50 E. Huron St., Chicago, IL 60611-2795; e-mail: ayoung@ala.org.
University of Nevada, Reno, has received two major gifts of more than $\$ 90,000$ from the E. L. Cord Founclation. The gift will fund the establishment of a computing lab, a computing help desk, and a computing instruction room in the main library. The lab is the largest general-access computing lab on the campus. Another major gift from Dr. and Mrs. Clinton Chase of Bloomington, Indiana, established the Patricia L. Chase Study Area, which includes a large room for quiet study, several conference rooms for group study and seminars, and an instruction/teaching room for multimedia presentations. Patricia Chase graduated from the University of Nevada, Reno, in 1957 with a degree in psychology.

\section{AngloState University has receivedagift} of $\$ 125,000$ from Eva Camunez Tucker for the West Texas Collection. Most of the gift $(\$ 100,000)$ will be used to start an endowment fund. The interest from the endowment will be used for supplementing the salary of the individual in charge of the collection and various forms of collection development. The remainder of the gift is for an immediate salary enhancement for the head of the collection and for a one-year, part-time collections specialist.

\section{Acquisitions}

\section{The Democratic Party of Hawaii records}

(1960-90) have been acquired by the University of Hawaii at Manoa. In making the gift, the Party Chair, Judge Walter Heen, recognized that the records would complement the library's other primary source materials relating to Hawaii's political history since statehood. These incluck the gifts that form the cornerstones of the library's newly established Hawaii Congressional Papers Collection: the Congressional Papers of Senator Spark M. Matsunaga, donated to the library by his family in 1997, and the Congressional Papers of Senator Hiram L. Fong, donated by the Senator in 1998. 
Extensive collections of works by John Dos

Passos and Rockwell Kent-as well as publications by Dylan Thomas, William Faulkner and John Barth-have been donated to Johns Hopkins University by alumnus Richard Frary. The Dos Passos collection includes the novels Manhattan Transfer and USA, clrama, poetry, history, and controversial works from every stage of his career. A 1927 pamphlet he wrote in support of Sacco and Vanzetti is included with a 1959 book by the conservative William F. Buckley Jr., for which Dos Passos wrote an introduction. Kent's collection includes reproductions of his paintings, a catalog of raisonne of his prints, and book illustrations he created for writers as different as Shakespeare, the '20s humorist George Chappell, and Kent himself. Also an author of nonfiction, Kent based his work on his personal experience, and proofs of the pictures for one of his books, $\mathrm{N}$ by $\mathrm{E}$-an account of a voyage to Greenland in 1929 are among the highlights of the collection.

\section{A collection of papers from the Blow fam-} ily, a prominent family in Southside, Virginia, is owned by the College of William and Mary. The collection documents mercantile and plantation life through voluminous correspondence, ledgers, drawings, legal papers, memorandum books, bills and receipts, and covers several generations of Blows from $1750-1900$. The pen and ink sketch below is of merchant and shipowner Richard Blow of "Tower Hill," in Sussex County, Virginia. It is one of a number of original sketches from the Blow Family Papers.

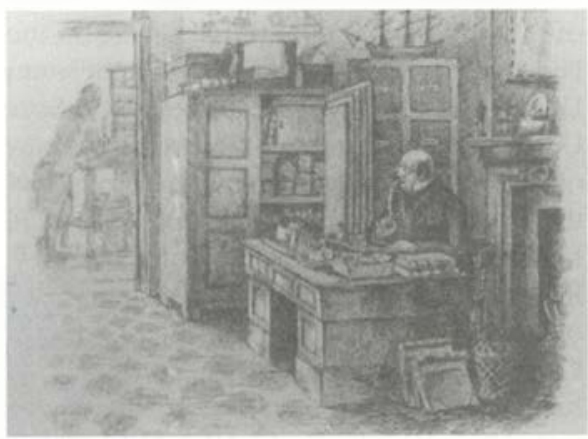

Richard Blow seated at his desk. This sketch is from the Blow Family Papers in Swem Library at the College of William and Mary.

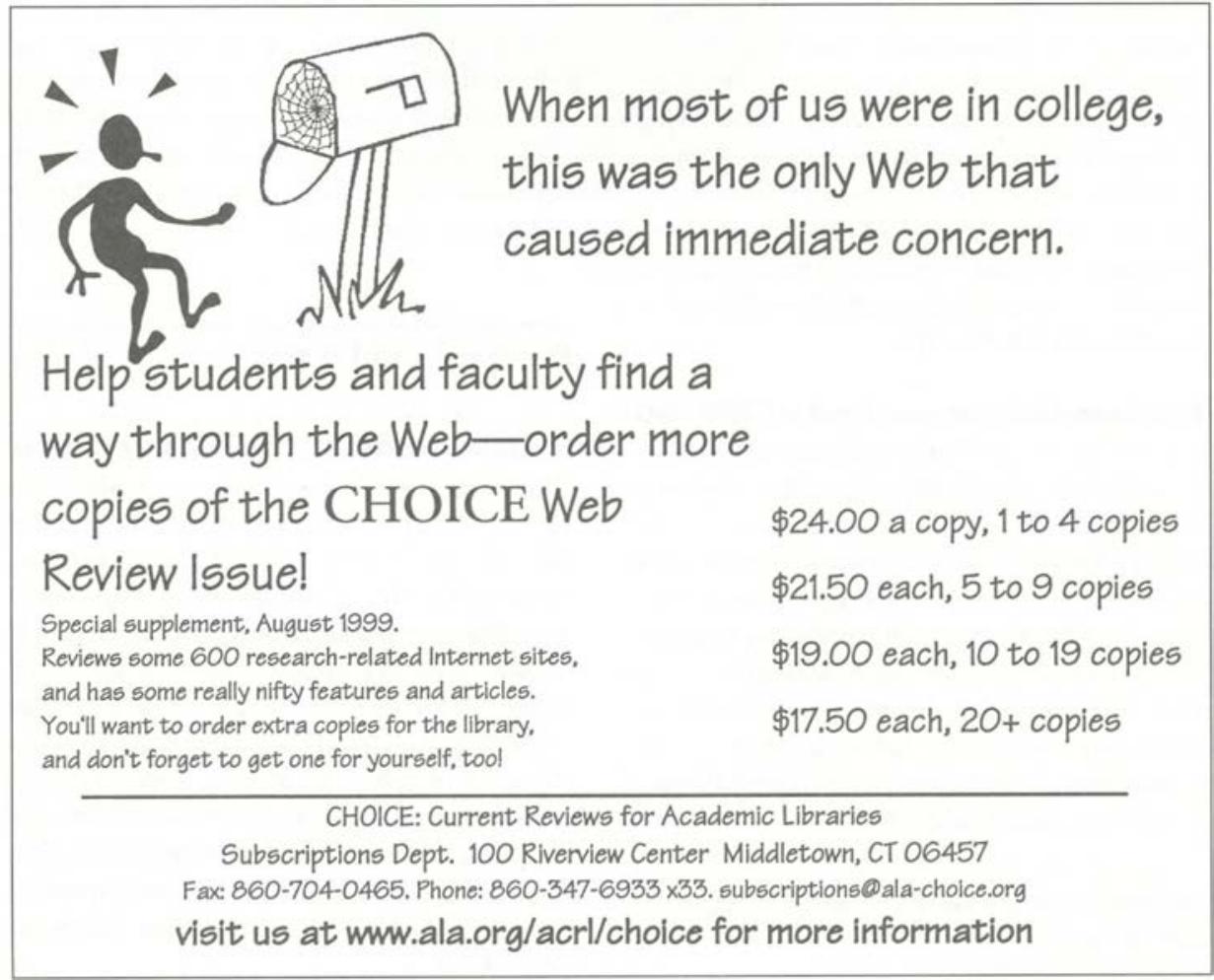

